\title{
Intraocular pressure in schizophrenic patients treated with psychiatric medications
}

\author{
Pressão intra-ocular em pacientes esquizofrênicos tratados \\ com medicações psiquiátricas
}

\author{
Valéria Barreto Novais e Souza ${ }^{1}$ \\ Francisco José Rodrigues de Moura Filho \\ Fábio Gomes de Matos e Souza ${ }^{3}$ \\ Sergio Aug'usto Carvalho Pereira Filho ${ }^{4}$ \\ Suele Serra Coelho ${ }^{5}$ \\ Fernando Antônio Mendes Lopes Furtado ${ }^{6}$ \\ Tiago Bessa Almeida Gonçalves ${ }^{7}$ \\ Karla Feitosa Ximenes Vasconcelos ${ }^{8}$
}

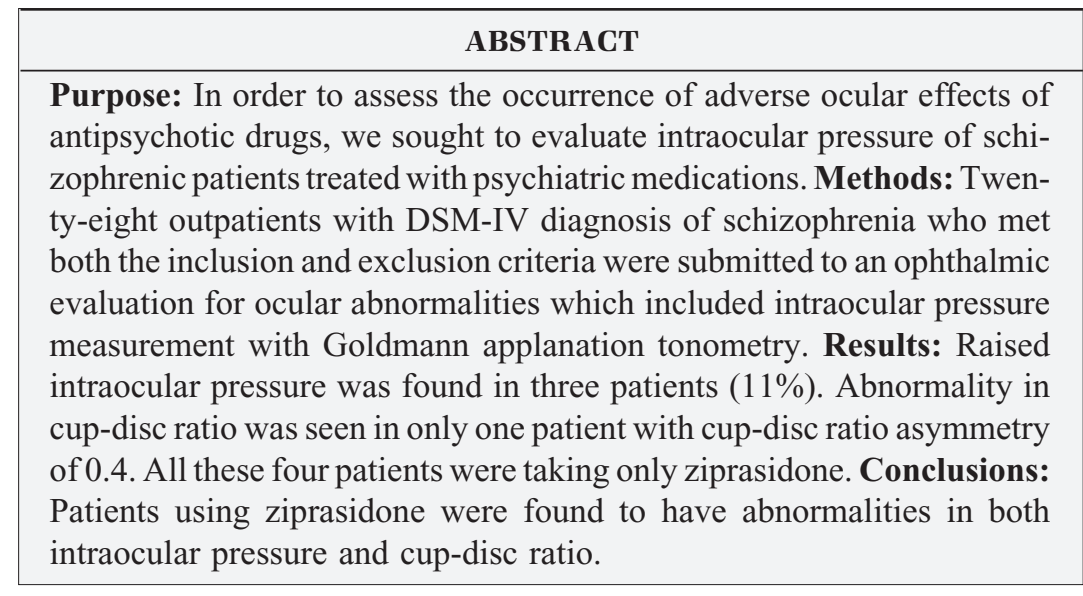

Keywords: Intraocular pressure; Schizophrenia/drug therapy; Polypharmacy; Antipsychotic agents/adverse effects; Glaucoma

\footnotetext{
Trabalho realizado no Serviço de Saúde Mental do Hospital Universitário Walter Cantideo - HUWC - Fortaleza (CE) - Brasil.

Doutora em Farmacologia da Universidade Federal do Ceará - UFC - Fortaleza (CE) - Brasil. Médica Psiquiatra do Serviço de Saúde Mental do Hospital Universitário Walter Cantideo - HUWC - Fortaleza (CE) - Brasil.

${ }^{2}$ Acadêmico de Medicina da UFC - Fortaleza (CE) - Brasil.

${ }^{3} \mathrm{PhD}$ da Universidade de Edimburgo. Professor adjunto de Psiquiatria do Departamento de Medicina Clínica da UFC - Fortaleza (CE) - Brasil.

${ }^{4}$ Acadêmico de Medicina da UFC - Fortaleza (CE) - Brasil.

${ }^{5}$ Acadêmico de Medicina da UFC - Fortaleza (CE) - Brasil.

${ }^{6}$ Oftalmologista Coordenador do Serviço de Uveítes da

Residência Médica da Sociedade de Assistência aos Cegos do Ceará - SAC - Fortaleza (CE) - Brasil.

${ }^{7}$ Residente de Oftalmologia da SAC - Fortaleza (CE) -

Brasil.

${ }^{8}$ Residente de Oftalmologia da SAC - Fortaleza (CE) -

Brasil.

Correspondence to: Valeria Barreto Novais e Souza

Rua Manoel Jesuíno, 974 - Fortaleza (CE)

CEP 60175-270

E-mails: valbns@yahoo.com.br

drmourafilho@yahoo.com.br

Recebido para publicação em 17.02.2008

Última versão recebida em 11.06.2008

Aprovação em 09.07.2008
}

\section{INTRODUCTION}

Schizophrenia is a mental illness whose onset of symptoms typically occurs in young adulthood ${ }^{(1)}$ with approximately $1 \%$ of the world's population affected ${ }^{(2)}$. This illness leads to impairment of some psychic functions, and because of its chronic character schizophrenic people have to take psychiatric medications lifelong, in many cases several of these drugs concomitantly. Once they are exposed to different drugs with anticholinergic, adrenergic or serotoninergic properties they can experience ocular adverse effects as a result of these properties such as precipitation or exacerbation of acute angle closure glaucoma as well as intraocular pressure (IOP) raise ${ }^{(3)}$, which is the main risk factor for the development of primary open-angle glaucoma ${ }^{(4)}$.

Intraocular pressure (IOP) is determined by a balance between aqueous humor production and its drainage. This regulation is in part done by neurotransmitters (noradrenalin, adrenalin, acetylcholine, dopamine, serotonin) that activate receptors placed on the ciliary body and trabecular meshwork ${ }^{(4-6)}$.

Antipsychotic drugs are the cornerstone of the management of schizophrenia, and they are divided into two categories: typical and atypical antipsychotics. The typical ones block dopamine postsynaptic receptors, mainly D2, as well as having activity on three more receptors: histamine H1 blockade, alpha1 adrenergic receptor blockade and muscarinic cholinergic M1 receptor blockade ${ }^{(7)}$. Muscarinic cholinergic receptor blockade, caused 
mainly by phenothiazines such as chlorpromazine, levomeprazine, thioridazine and fluphenazine, may lead to raise in intraocular pressure due to mydriasis and angle closure ${ }^{(8)}$.

The selective serotonin reuptake inhibitors (SSRI) class could be involved in raising IOP due to its serotoninergic action. Some studies have shown acute angle closure glaucoma and IOP raise in patients using SSRI drugs, possibly due to 5-HT action ${ }^{(9-11)}$. 5-HT receptors have already been demostraded in the human eye $\mathrm{e}^{(12-14)}$.

Tryciclic antidepressants due to their anticholinergic proprieties can also lead to acute angle closure glaucoma or worsen primary open-angle glaucoma because of their potential of causing mydriasis ${ }^{(15-16)}$. This action is enhanced by monoamine oxidase inhibitors ${ }^{(15)}$.

Atypical antipsychotic drugs are serotonin-dopamine antagonists, and this serotonin-dopamine antagonism is a key concept to explain some of the atypical clinical actions of several atypical antipsychotics ${ }^{(7)}$. Up till now, there is no known association between agents of this new generation and raised IOP. On the other hand, two atypical antipsychotics, sulpiride and clozapine, were found to have hypotensive intraocular pressure activity ${ }^{(17)}$.

In spite of the potential effects of these psychiatric drugs for either raising IOP or exacerbating acute closed-angle glaucoma, studies have not been demonstrating high rates of both IOP increase and glaucoma in patients using those drugs ${ }^{(16,18-23)}$. However, an ophthalmic evaluation is recommended before the tricyclic antidepressant drug therapy, which are the main agents involved in this side effect, and in patients with narrow anterior chamber angle these drugs must be avoided ${ }^{(3,15)}$.

Once schizophrenic patients are theorically exposed to several drugs with a potential to lead to either intraocular pressure abnormalities or glaucoma, it is important to evalute both their IOP and their eye fundus in order to detect possible glaucomatous changes as early as possible and prevent their complications such as blindness. In addition, it is always useful in management of this group of patients to know adverse effects related to psychiatric medications to guide physicians with more effective treatments enabling them to offer prompt specific treatment regarding their complications or switch to another class of drugs with equivalent therapeutic efficacy. Another relevant point is that the use of atypical antipsychotics has become more common and there is little knowledge on the possible ocular adverse effects of these drugs.

The aim of this study was to evaluate the intraocular pressure of schizophrenic patients treated with psychiatric medications.

\section{METHODS}

A total of 28 outpatients attending Mental Health Service at the "Walter Cantideo" University Hospital, treated with psychiatric medications, participated in this cross-sectional study in which patients were selected during the year of 2005.

The inclusion criteria were: patients with DSM-IV (APA, 1994) diagnosis of schizophrenia aged 18 to 60 years who had been taking antipsychotic drugs (typical, atypical or both) for at least two years, the inclusion of those in concomitant use of either tricyclic antidepressants, selective serotonin reuptake inhibitors, benzodiazepines and anticholinergic drugs (promethazine and biperiden) being allowed. The exclusion criteria were: patients who had diabetes, systemic arterial hypertension, previously diagnosed ocular diseases (glaucoma, retinopathies, corneal diseases), family history of either glaucoma or blindness, and patients who had taken corticosteroids, amiodarone or had had any ocular trauma. No patients with symptoms of acute angle closure glaucoma were included. Increased intraocular pressure was definied as being greater than $21 \mathrm{mmHg}$. Glaucomatous damage to cupdisc was definied as asymmetry of cup-disc ratio $>0.2$ between eyes, localized loss of neural rim, optic disc hemorrhage, cup-disc ratio $\geq 0.6$, the thickness of the neural rim not following the ISN'T rule, which says that the inferior rim is the thickest, followed by the superior rim, the nasal rim, and the temporal rim in order of decreasing thickness.

This study was approved by The Ethics Committee of the Federal University of Ceará and the participants signed a consent form agreeing to participate in this study. They were submitted to an ophthalmological evaluation at the "Sociedade de Assistência aos Cegos (SAC)" Iêda Otoch Baquit Ophthalmological Unit, by doctors who were blind to the medication used by patients, that incuded maximum visual acuity examination with optical correction, biomicroscopy of the anterior segment with empahsis on cornea and lens, fundus biomicroscopy, ultrasound pachymetry, intraocular pressure measurement with Goldmann applanation tonometry performed during the morning between 7 and 10 a.m, gonioscopy and a biomicroscopy reexamination under mydriasis.

Demographic and clinical data were obtained by interviewing the patients and analyzing patient's records. The duration and dose of currently used psychotropic drugs were obtained.

The obtained data were analyzed using the Statistical Package Social Sciences (SPSS) software and presented in the form of descriptive statistics of means, standard deviations and frequencies. The data distribution was tested the Kolmogorov-Smirnov test. Inferential statistics were also applied in the form of Pearson's correlation. The significance level was set at $\mathrm{p}>0.05$ (two-tailed). Ophthalmic data were described considering two eyes for each patient.

\section{RESULTS}

Of the 28 patients, 19 were male $(67.9 \%)$ and 9 female (32.1\%). Their age ranged from 20 to 50 years $(35.89 \pm 10.23)$.

Four patients were on only typical antipsychotics (14.3\%), sixteen were on only atypical antipsychotics (57.1\%), and eight were on both typical and atypical antipsychotics (29.6\%). 
Eleven patients $(39 \%)$ were on phenothiazines (thioridazine, fluphenazine, levomeprazine, chlorpromazine).

Table 1 provides information on dosages and duration of antipsychotic drugs use, and Table 2 describes the percentage of each single antipsychotic drug used by patients of this study.

Eight patients $(29 \%)$ were using anticholinergic drugs, six were on promethazine and two on biperiden. These patients did not have intraocular pressure abnormalities. Benzodiazepines (alprazolan, nitrazepan, diazepan) were used by six patients $(21 \%)$, who also had no IOP raise.

The majority of patients were not using antidepressants $(n=23)(82 \%)$. Four patients $(14.3 \%)$ were on tricyclic antidepressants (amitryptiline, imipramine) and only one patient $(3.6 \%)$ was on selective serotonin reuptake inhibitor (sertraline). None of them had raised intraocular pressure.

The best-corrected visual acuity was normal in 46 eyes $(82 \%)$. A slight reduction of visual acuity was found in 9 eyes $(16 \%)$, and only one eye (2\%) had moderate reduction of its visual acuity (Table 3 ). As for optic disc cup, just one patient had a cup-disc ratio (CDR) asymmetry of 0.4 . He was only on ziprasidone. The others had no changes in their optic disc. Anterior capsular clouding was found in seven patients $(25 \%)$. No changes were found in the cornea. The mean central corneal thickness (CCT) was $545 \pm 10 \mu \mathrm{m}$.

Four eyes out of 56, from three different patients, were found to have raised intraocular pressure (Table 4). In the right eyes, intraocular pressure ranged from $10 \mathrm{mmHg}$ to $24 \mathrm{mmHg}$ $(14.1 \pm 3.61)$ as well as in the left eyes $(14.3 \pm 3.57)$. All three patients (11\%) in whom an abnormal intraocular pressure was found were taking only ziprasidone, an atypical antipsychotic. No other drugs, such as antidepressants, benzodiazepines, typical antipsychotics, and anticholinergic drugs, were being used by these three patients. Gonioscopy did not yield abnormalities in any eye of the patients of this study, showing open angle in all 56 examined eyes.

The suggestive findings of glaucoma, raised intraocular pressure and asymmetry of cup-disc ratio $>0.2$ between eyes, showed a significant correlation with ziprasidone use $(\mathrm{r}=0.38 ; \mathrm{p}=0.046)$.

\section{DISCUSSION}

Patients with schizophrenia due to polypharmacy are exposed to several drugs with a potential of acting on intraocular pressure. In the present study, we found abnormalities in both intraocular pressure and cup-disc ratio.

No patients who were using typical antipsychotic drugs had raised intraocular pressure. Reid et al (1976) found that even in patients taking high levels of typical antipsychotics there was no IOP increasing ${ }^{(3)}$. Actually, phenothiazes have a low potential to induce intraocular pressure abnormalities by mydriasis since they have weak anticholinergic proprieties ${ }^{(15)}$. In addition, gonioscopy showed open angle in all patients of this study, which could have favored not to find IOP increase

\begin{tabular}{lr}
\hline Table 1. Current dosage and duration of antipsychotic drugs use \\
$\begin{array}{l}\text { Current dosage of typical antipsychotic } \\
\text { drugs at chlorpromazine-equivalent } \\
\text { as mg/day (mean } \pm \mathrm{SD} \text { ) }\end{array}$ \\
$\begin{array}{l}\text { Current dosage of atypical antipsychotic } \\
\text { drugs at chlorpromazine-equivalent }\end{array}$ \\
$\begin{array}{l}\text { as mg/day (mean } \pm \mathrm{SD} \text { ) } \\
\begin{array}{l}\text { Duration of antipsychotic drug use in } \\
\text { months at current dosage (mean } \pm \mathrm{SD} \text { ) }\end{array}\end{array}$ \\
\end{tabular}

Table 2. Percentage of each single antipsychotic drug used in this study

\begin{tabular}{lrr} 
Antipsychotic drug & \multicolumn{1}{c}{ Typical } & Atypical \\
Levomeprazine & $21 \%(n=6)$ & \\
Haloperidol & $18 \%(n=5)$ & \\
Chlorpromazine & $11 \%(n=3)$ & \\
Thioridazine & $4 \%(n=1)$ & \\
Fluphenazine & $4 \%(n=1)$ & \\
Zuclopentixol & $4 \%(n=1)$ & \\
Olanzapine & & $39 \%(n=11)$ \\
Ziprasidone & & $39 \%(n=11)$ \\
\hline
\end{tabular}

\begin{tabular}{lcr|}
\hline Table 3. The best-corrected visual acuity of the $\mathbf{5 6}$ examined eyes \\
Visual Acuity & Eyes (n) & $\%$ \\
$20 / 20$ & 46 & 82 \\
$20 / 25$ & 3 & 5 \\
$20 / 30$ & 6 & 11 \\
$20 / 100$ & 1 & 2 \\
\hline
\end{tabular}

\begin{tabular}{|c|c|c|c|}
\hline & Right Eye & Left Eye & ССТ \\
\hline Patient A & $21 \mathrm{mmHg}$ & $24 \mathrm{mmHg}$ & $540 \mu \mathrm{m}$ \\
\hline Patient B & $23 \mathrm{mmHg}$ & $21 \mathrm{mmHg}$ & $537 \mu \mathrm{m}$ \\
\hline Patient C & $24 \mathrm{mmHg}$ & $24 \mathrm{mmHg}$ & $539 \mu \mathrm{m}$ \\
\hline
\end{tabular}

in these patients on typical antipsychotic drugs, once they did not have anatomically predisposed eyes.

All three patients $(11 \%)$ with raised intraocular pressure (IOP) were using only ziprasidone. This drug has specifically more affinity for serotonin receptors, especially serotonin type 2A (5-HT2A) and has high affinity for dopamine receptors type 2 (D2). It is also a strong agonist of 5HT1 A receptor and inhibits serotonin and norepinephrine reuptake ${ }^{(24)}$. Ziprasidone is unique to the atypical armamentarium because it is the only one that is a serotonin 1D (5-HT1D) antagonist, a serotonin 1A (5-HT1A) agonist, and a reducer of the synaptic reuptake of both serotonin and norepinephrine ${ }^{(25)}$.

An asymmetry of the cup-disc ratio greater than 0.2 between eyes is suggestive of glaucoma ${ }^{(4)}$. In this study, the pa- 
tient that had this abnormality, a 20 -year-old man, presented a CDR of 0.7 in the right eye and 0.3 in the left eye and was using only ziprasidone. His intraocular pressure was $18 \mathrm{mmHg}$ in right eye and $12 \mathrm{mmHg}$ in left eye. He was submitted to a gonioscopy that showed open angle.

Some animal studies have shown the involvement of serotonin in intraocular pressure regulation. Serotoninergic stimulation was shown to be able to cause mydriasis besides having an independent effect in raising the intraocular pressure $^{(11)}$. Serotonin receptors were also demonstrated to be present in the human eye ${ }^{(12)}$. Serotonin $(5-\mathrm{HT})$ is present in iris ciliar body and cornea of mammals at higher concentrations than in non-mammalian species ${ }^{(13)}$. Experimental evidences also revealed that topic serotonin administration in rabbit eyes increased IOP and that 5-carboxamidotryptamine (5-CT), a 5-HT1A receptor agonist, is even more effective in raising IOP than serotonin itself ${ }^{(26)}$. Ziprasidone has already been shown to be a serotonin 1A (5-HT1A) agonist ${ }^{(27)}$.

Normal levels of IOP range between 12 and $21 \mathrm{mmHg}$. Intraocular pressure obeys a daily variation so that we can observe the higher levels in the morning and the lower at night. The mean variation of IOP in healthy individuals is about $5 \mathrm{mmHg}$ being even higher in patients with ocular hypertension or open angle glaucoma ${ }^{(2)}$. In addition, IOP may be influenced by other factors such as heart rate, blood pressure and respiratory rate ${ }^{(4)}$. Therefore, a single measure of IOP may not be reliable.

A significant correlation between suggestive findings of glaucoma and ziprasidone use was found, but this result may be due to our small sample. Ziprasidone could act on intraocular pressure in the same way as selective serotonin reuptake inhibitors (SSRI). However, if there is any association between ziprasidone and raised IOP, it needs to be proved only by controlled clinical trials.

Our findings support the view that patients on drugs with affinity for serotonin receptors such as ziprasidone should be submitted to an ophthalmic examination, once there is a possibility of them to lead to intraocular pressure abnormalities. Identification of these findings might provide monitoring and early specific treatment.

\section{CONCLUSION}

In this study, patients using ziprasidone were found to have abnormalities in both intraocular pressure and cup-disc ratio.

Further prospective studies are necessary to replicate these findings using a design that controls the drugs per dose and duration of intake.

\section{RESUMO}

Objetivo: Para avaliar a ocorrência de efeitos adversos oculares dos antipsicóticos, buscamos avaliar a pressão intra-ocular em pacientes esquizofrênicos tratados com medicações psiquiátricas. Métodos: Vinte e oito pacientes tratados ambulatorialmente com diagnóstico de esquizofrenia segundo o DSM-IV que preencheram os critérios de inclusão e exclusão foram submetidos a uma avaliação oftalmológica para pesquisa de alterações oculares que incluiu a medida da pressão intra-ocular com tonometria de aplanação de Goldmann. Resultados: Pressão intra-ocular aumentada foi encontrada em 3 pacientes (11\%). Anormalidade na escavação do disco óptico foi observada em apenas um paciente com assimetria de escavação de 0,4. Todos esses quatro pacientes estavam usando apenas ziprasidona. Conclusões: Pacientes em uso de ziprasidona apresentaram anormalidades na pressão intra-ocular e na escavação do disco óptico.

Descritores: Pressão intra-ocular; Esquizofrenia/quimioterapia; Polimedicação; Agentes antipsicóticos/efeitos adversos; Glaucoma

\section{REFERENCES}

1. Castle E, Wessely S, Der G, Murray RM. The incidence of operationally defined schizophrenia in Camberwell, 1965-84. Br J Psychiatry.1991;159: 790-4. Comment in: Br J Psychiatry. 1992;160:712.

2. Regier DA, Burke JD. Psychiatry disorders in the community: the Epidemiological Catchment Area Study. In: Hales RD, Frances AJ, editors. American Psychiatry Association Annual Review. Washington: American Psychiatry Association; 1987. v.6, p.610-24.

3. Reid WH, Blouin P. Outpatient psychiatric medications and glaucoma. Psychosomatics.1976;17(2):83-5.

4. Kanski JJ. Clinical ophthalmology. $5^{\text {th }}$ ed. Oxford (UK): Butterworth-Heinemann; 2006

5. Dantas AM. Anatomia funcional do olho e seus anexos. $2^{\underline{a}}$ ed. Rio de Janeiro: Colina Editora; 2002.

6. Yanoff M, Duker JS. Ophthalmology. $2^{\text {nd }}$ ed. Philadelphia: Mosby; 2004.

7. Stahl SM. Psicofarmacologia: bases neurocientíficas e aplicações clínicas. Rio de Janeiro: MEDSI; 1998.

8. Lin K, Casagrande M. Psicofármacos em pacientes com doenças ou problemas físicos [Internet]. [citado 2007 Ago 17]. Disponível em: http://www.ccs.ufsc. br/psiquiatria/981-12.html.

9. Eke T, Bates AK. Acute angle closure glaucoma associated with paroxetine. BMJ. 1997;314(7091):1387.

10. Costagliola C, Mastropasqua L, Steardo L, Testa N. Fluoxetine oral administration increases intraocular pressure. Br J Ophthalmol. 1996;80(7):678. Erratum in: Br J Ophthalmol. 2002;86(6):707. Comment in: Br J Ophthalmol. 1998;82(8):976-8.

11. Osborne NN. Serotonin and melatonin in the iris/ciliary processes and their involvement in intraocular pressure. Acta Neurobiol Exp (Wars).1994;54 Suppl:57-64.

12. Barnett NL, Osborne NN. The presence of serotonin (5-HT1) receptors negatively coupled to adenylate cyclase in rabbit and human iris-ciliary processes. Exp Eye Res. 1993;57(2):209-16.

13. Osborne NN, Tobin AB. Serotonin-accumulating cells in the iris-ciliary body and cornea of various species. Exp Eye Res. 1987;44(6):731-45.

14. Costagliola C, Iuliano G, Rinaldi M, Russo V, Scibelli G, Mastropasqua L. Effect of topical ketanserin administration on intraocular pressure. Br J Ophthalmol. 1993;77(6):344-8.

15.Oshika T. Ocular adverse effects of neuropsychiatric agents. Incidence and management. Drug Saf. 1995;12(4):256-63.

16. Lowe RF. Amitriptyline and glaucoma. Med J Aust. 1966;2(11):509-10.

17. Lin TH, Chen IJ. Hypotensive intraocular pressure activity of clozapine and sulpiride. United States Patent 5744468 [Internet]. [cited 2007 Aug 17]. Available from: http:/www.freepatentsonline.com/5744468.html

18. Hollister LE. Adverse reactions to phenothiazines. JAMA. 1964;189:311-3.

19. Grant WM. Ocular complications of drugs. Glaucoma. JAMA. 1969;207(11): 2089-91. Review. 
664 Intraocular pressure in schizophrenic patients treated with psychiatric medications

20. Lazenby GW, Reed JW, Grant WM. Anticholinergic medication in openangle glaucoma. Long-term tests. Arch Ophthalmol. 1970;84(6):719-23.

21. Grant WM. Systemic drugs and adverse influence on ocular pressure. In Leopold IH, editor. Symposium on ocular therapy. St. Louis: C.V. Mosby Co; 1968. v.3.

22. Bryant JA. Effects of systemic drugs on intraocular pressure. J Iowa Med Soc. 1969;59(2):130-1.

23. Hiatt RL, Fuller IB, Smith L, Swartz J, Risser C. Systemically administered anticholinergic drugs and intraocular pressure. Arch Ophthalmol. 1970;84(6): 735-40.
24. PsiquiWeb. Antipsicóticos atípicos ou de $2^{\underline{a}}$ geração [Internet]. [citado 2007 Ago 16]. Disponível em: http://virtualpsy.locaweb.com.br/index.php?art=281 \&sec=61. 25. Crutchfiled DB. Ziprasidone: a new atypical antipsychotic. Geriatric Times. $2001 ; 2(5): 28-9$

26. Osborne NN, Meyer-Bothling U, Barnett NL. Serotonin receptors in the eye In: Anderson DR, Drance SM, editors. Encounters in Glaucoma Research 1 Receptor Biology and Glaucoma. Milan: Fogliazza Editore; 1994. p.331-64.

27. Rollema H, Sprouse JS, Lu Y, Reynolds LS, Braselton JP, Zorn SH. Ziprasidone: in vivo evidence of central $5 \mathrm{HT}_{1 \mathrm{~A}}$ agonist activity. Eur Psychiatry. 1998;13(Suppl 4):302s-303s 